\title{
TWO NEW SPECIES OF OCTOMERIA (PLEUROTHALLIDINAE) FROM CORDILLERA DEL CÓNDOR, ZAMORA CHINCHIPE, ECUADOR
}

\author{
Leisberth Vélez-Abarca ${ }^{1,4-5}$, Marco M. JimÉnez ${ }^{2,4} \&$ Luis E. Baquero ${ }^{3-4}$ \\ ${ }^{1}$ Carrera de Biología, Universidad Estatal Amazónica (Sede El Pangui), Luis Imaicela entre Azuay y \\ Mayor Rene Ulloa, El Pangui, Zamora Chinchipe, Ecuador. \\ ${ }^{2}$ Orquideario La Paphinia, Avenida del Ejército y Juan Izquierdo, Zamora, Zamora Chinchipe, 190102, \\ Ecuador. \\ ${ }^{3}$ Grupo de Investigación en Biodiversidad, Medio Ambiente y Salud BIOMAS, Carrera de Ingeniería \\ Agroindustrial y Alimentos, Facultad de Ingeniería y Ciencias Agropecuarias, Universidad de Las \\ Américas, Calle José Queri, Quito, Pichincha, 170137, Ecuador. \\ ${ }^{4}$ Grupo Científico Calaway Dodson: Investigación y Conservación de Orquídeas del Ecuador, Quito, \\ 170510, Pichincha, Ecuador. \\ ${ }^{5}$ Author for correspondence: leis.alexis92@gmail.com
}

\begin{abstract}
Aвstract. Two new species of orchids, Octomeria pacii, and O. panguiensis are described and illustrated from Cordillera del Cóndor, Ecuador; likewise, information is provided on their distribution, habitat, and conservation status. These species differ from other species in the genus by their floral and vegetative characteristics and their apparent reproductive strategy of cleistogamy. Octomeria pacii is similar to Octomeria deceptrix, but differs in the caespitose habit, the ramicauls compressed along their entire length, the narrowly elliptical leaves, the autogamous flowers, the translucent white sepals suffused with magenta and the obovate, white lip, marked with magenta. Octomeria panguiensis is similar to O. werneri, but differs by the larger, shortly repent plants with lanceolate leaves, the cleistogamous flowers, the translucent white-colored sepals, the 5 -veined lateral sepals and the oblong-trilobed lip with the apical lobe tridentate.
\end{abstract}

Resumen. Dos nuevas especies de orquídeas, Octomeria pacii y $O$. panguiensis, se describen e ilustran de la Cordillera del Cóndor, Ecuador; así mismo, se brinda información sobre su distribución, hábitat y estado de conservación. Estas especies difieren de otras en el género por las características florales y vegetativas y por la aparente estrategia reproductiva de cleistogamia. Octomeria pacii es similar a Octomeria deceptrix, pero difiere en el hábito cespitoso, los ramicaules comprimidos en toda su longitud, las hojas estrechamente elípticas, las flores autógamas, los sépalos blancos translúcidos y teñidos de magenta y el labio blanco obovado, manchado con magenta. Octomeria panguiensis es similar a $O$. werneri pero se diferencia por las plantas más grandes y repentes, con hojas lanceoladas, las flores cleistógamas, los sépalos translúcidos de color blanco, los sépalos laterales con 5 nervaduras y el labelo oblongo trilobulado con el lóbulo apical tridentado.

Keywords/Palabras clave: Autocompatibilidad, self-compatibility, autopolinizacion, self-pollination, cleistogamia, cleistogamy, Octomeria deceptrix, Octomeria werneri

Introduction. Octomeria $\mathrm{R}$.Br. includes around 160 species distributed from Belize to northern Argentina and the Antilles, with the center of diversity being from the Guianas to southern Brazil (Forster 2007, Forster et al. 2012, Karremans et al. 2019). Twentyseven species are described from Ecuador, Octomeria candidae Vélez-Abarca, M.M.Jiménez \& Baquero, being the most recent (Vélez-Abarca et al. 2020).
Plants of the genus are epiphytic, rupicolous, and more rarely, terricolous (Forster 2007); as well, repent to caespitose. The flowers are fasciculate to solitary, emerging from the apex of the ramicaul. The sepals and petals are generally similar in shape and color, but unequal in size, and the lateral sepals are free or occasionally connate. The column is semiterete, usually with a sub-apical anther and stigma, and the pol- 
linarium is generally made up of eight pollinia, hence the generic name, except for one species (O. splendida Garay \& Dunst.), which has six pollinia (Luer 2010).

Orchid species have evolved several floral characteristics that commonly ensure cross-pollination (Johnson \& Steiner 2000). Based on some studies of the pollination systems in Pleurothallidinae, it has been possible to determine that the orchid species within the subtribe are generally self-incompatible (Borba et al. 2001). According to the recent phylogenetic studies of Pleurothallidinae, Octomeria together with Atopoglossum, Brachionidium, and Sansonia form an early diverging group called Octomeria affinity (Karremans 2016) and is believed to be mostly self-incompatible and myophilic (Karremans \& Díaz-Morales 2019, dos Santos et al. 2020).

In a study carried out in Octomeria grandiflora Lindl. and $O$. crassifolia Lindl., self-incompatibility was confirmed. Also, these species are pollinated by flies of the Sciaridae family (Diptera), which are attracted by the nectar at the base of the lip (Barbosa et al. 2009). However, not all orchid species possess adaptations that ensure cross-pollination. Some have structural modifications in the flowers that ensure selfpollination, like a reduced or vestigial rostellum and a perianth which never opens (Catling 1990). Some examples of cleistogamy in Pleurothallidinae are: Masdevallia cleistogama Luer, some plants of Pabstiella tripterantha (Rchb.f.) F.Barros, Pleurothallis cleistogama Luer, and Restrepiella lueri Pupulin \& Bogarín (Luer 1998, 2001, 2006, Pupulin \& Bogarín 2007). Here, we described two new species of Octomeria recently discovered in the southeast of Ecuador with the adaptation to self-pollination, one of them exhibits cleistogamy.

Material and methods. Specimens were collected during a comparative study on the orchids of the Cordillera del Cóndor. Some of these were grown and photographed at the Orquideario la Paphinia in Zamora, Ecuador. The measurements of the vegetative and floral parts were made from living material. Photographs were taken using a Panasonic ${ }^{\circledR}$ FZ300 or Canon ${ }^{\circledR}$ EOS 1100D camera and Raynox DCR-150 50 $\mathrm{mm}$, EFS 18-58 mm, and +10 Kernel Pro Optics 58 $\mathrm{mm}$ close-up lenses. The new species were compared to those previously described (Luer 2010, Luer 2011).

\section{TAXONOMIC TREATMENT}

Octomeria pacii Vélez-Abarca, M.M.Jiménez \& Baquero, sp.nov. (Fig. 1, 2A, 3A, 4).

TYPE: Ecuador. Zamora: Chinchipe, Cordillera del Cóndor flank, 1010 m, 12 Oct. 2020, L. Vélez LV0020 (holotype: ECUAMZ!)

Diagnosis: Similar to Octomeria deceptrix Luer, but differs in the caespitose habit ( $v s$. shortly repent), the ramicauls compressed along their entire length ( $v s$. ramicauls terete below, compressed above) with narrowly elliptical leaves $(1.5-2.5 \mathrm{~cm}$ wide $v s$. ellipticalovate, $1.5-3.0 \mathrm{~cm}$ wide), the translucent white suffused with magenta sepals (vs. white to yellow, often suffused with rose), the obovate, white, marked with magenta lip, (vs. yellow, suffused with red-purple, oblong) and the laterally ribbed column (vs. smooth). Octomeria pacii is also distinguished by the autogamous flowers (vs. allogamous).

Plant medium in size, up to $23 \mathrm{~cm}$ tall, epiphytic, caespitose. Roots slender, undulated, $1 \mathrm{~mm}$ in diameter. Ramicauls stout, erect, 8-14 cm long, ancipitous below, with 3-5 internodes enclosed by imbricating, tubular sheaths, the lower sheath shorter than the rest. Leaf erect, coriaceous, narrowly elliptical $8-15 \times 1.5-2.5 \mathrm{~cm}$, sulcate adaxially and slightly carinate abaxially, margin entire, apex acute, cuneate below into a $0.5-1.5 \mathrm{~cm}$ long petiole. Inflorescence single-flowered, produced from a fascicle at the apex of the ramicaul, peduncle cylindrical $1 \mathrm{~mm}$ long; floral bract tubular, $3 \mathrm{~mm}$ long; pedicel cylindrical, $2 \mathrm{~mm}$ long; ovary 3.5-4.0 $\mathrm{mm}$ long, terete, longitudinally sulcate. Sepals translucent white suffused with magenta, free, glabrous. Dorsal sepal ovate, subacute 9-11 × 5-6 mm, 5-veined. Laterals sepals free, ovate, acute, 9-11 × 3-4 mm, 5-veined, oblique. Petals translucent white with suffused with magenta, elliptical-ovate, acute, $10-11 \times 3-4 \mathrm{~mm}$, 3-veined. Lip white, marked centrally with magenta, glabrous, panduriform, trilobated, with erose apical margins, the apex minutely cuspidate, $6.0 \times 3.5 \mathrm{~mm}$; the lateral lobes erect, oblique, subacute, antrorse, below the middle, the disc with a pair longitudinal, slightly crooked calli emerging at the middle; the base broadly truncate, hinged to the column-foot. 


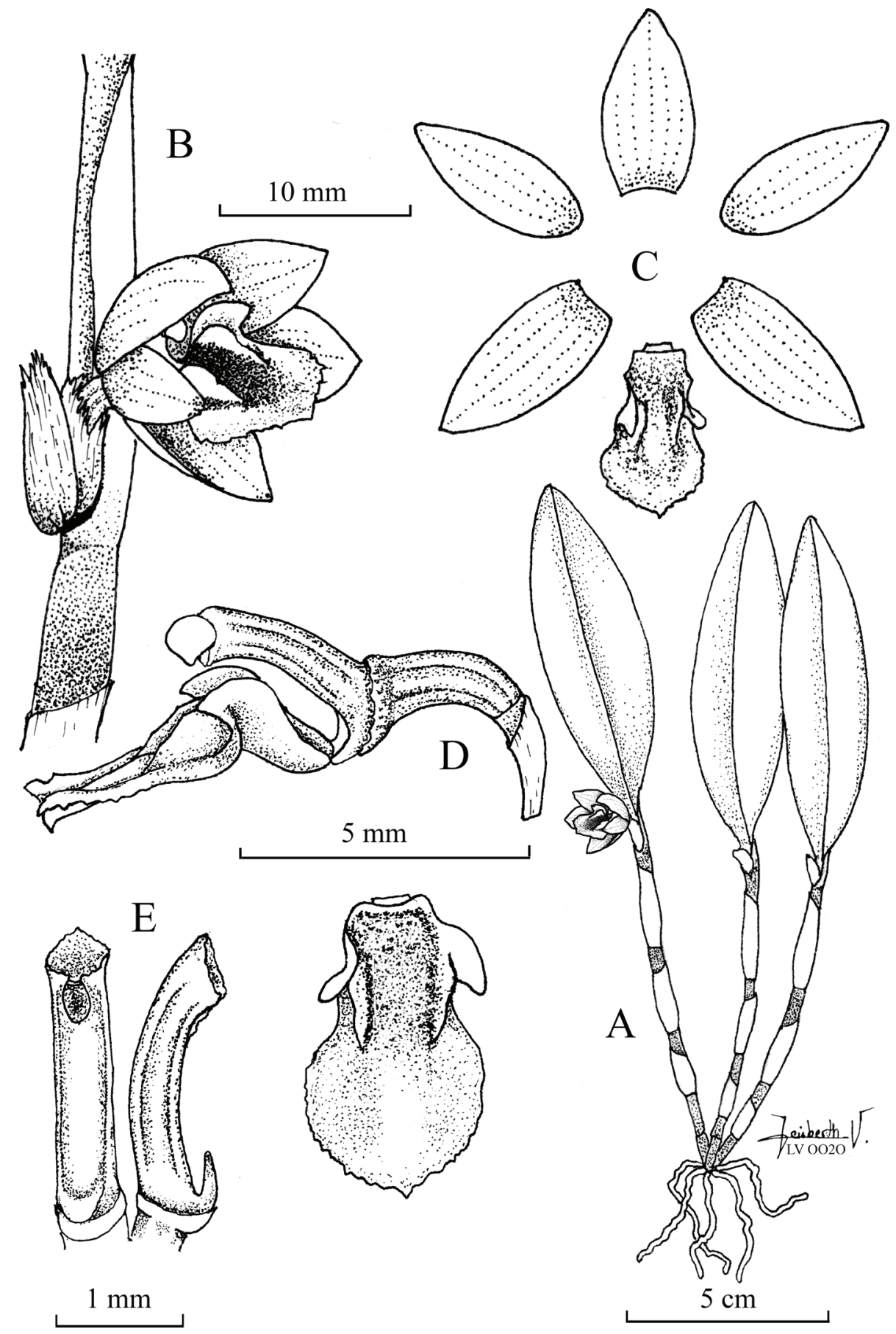

Figure 1. Octomeria pacii Vélez-Abarca, M.M.Jiménez \& Baquero. A. Habit. B. Flower in 3/4 view. C. Dissected perianth. D. Part of the pedicel, ovary, column and lip in lateral view and lip adaxial view. E. Column in ventral and lateral view. Illustration by Leisberth Vélez, based on the holotype, Vélez-Abarca LV-0020 (ECUAMZ). 


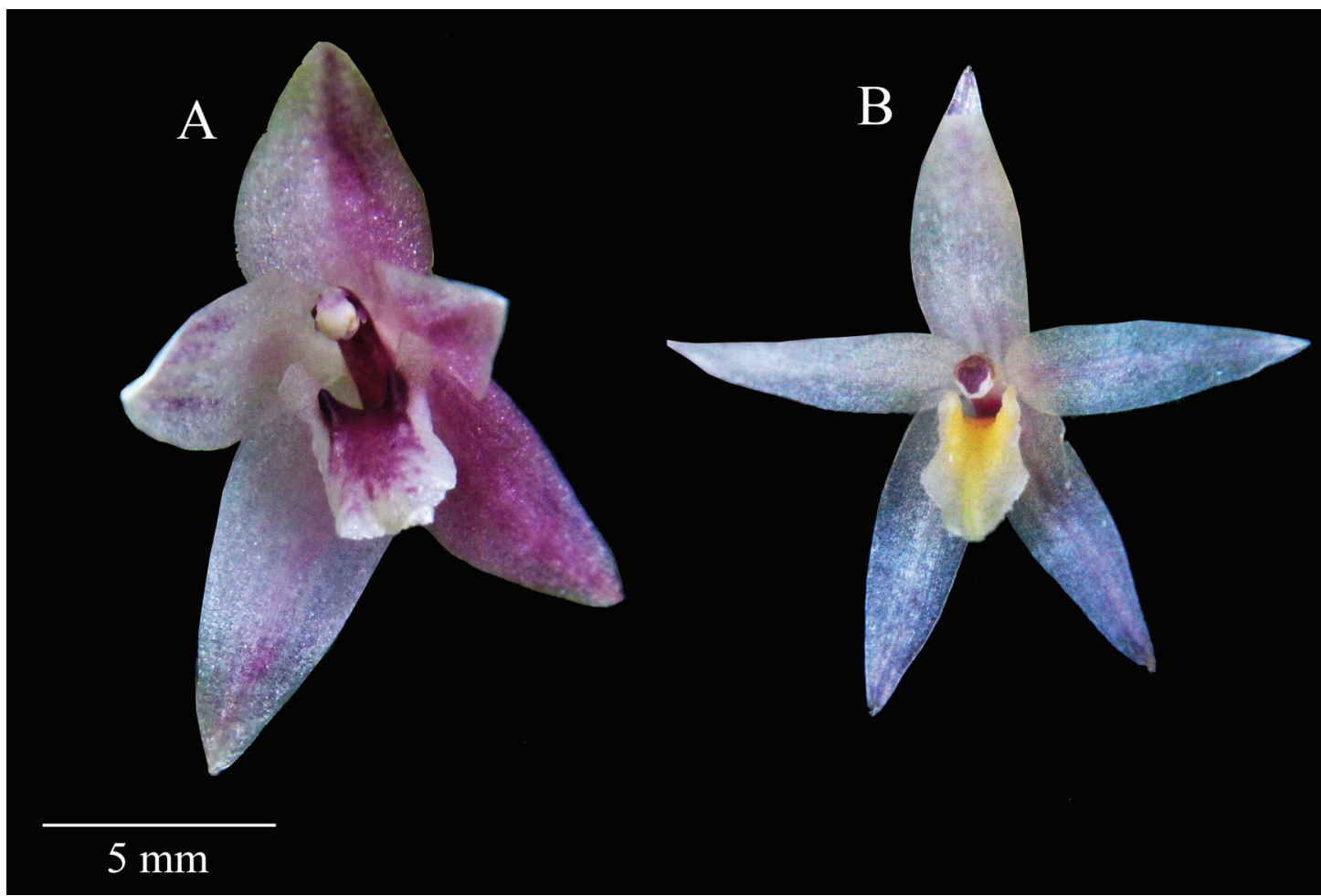

Figure 2. Comparison of flowers. A. Octomeria pacii Vélez-Abarca, M.M.Jiménez \& Baquero, in situ. B. Octomeria deceptrix Luer, in situ. Photos by Leisberth Vélez.

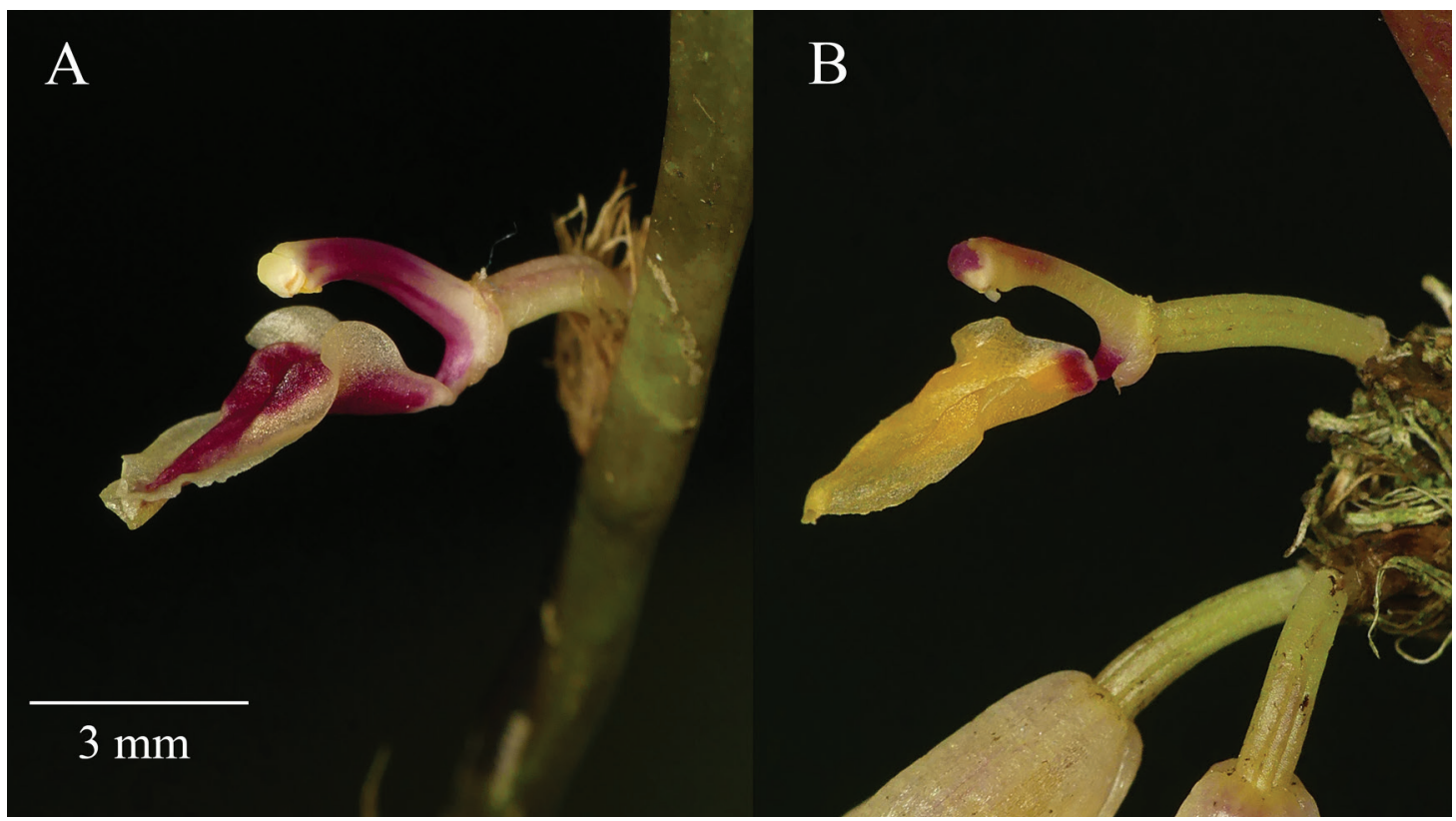

Figure 3. Comparison of the ovary, column and lip in lateral view. A. Octomeria pacii Vélez-Abarca, M.M.Jiménez \&

Baquero. B. Octomeria deceptrix Luer. Photos by Marco M. Jiménez. 


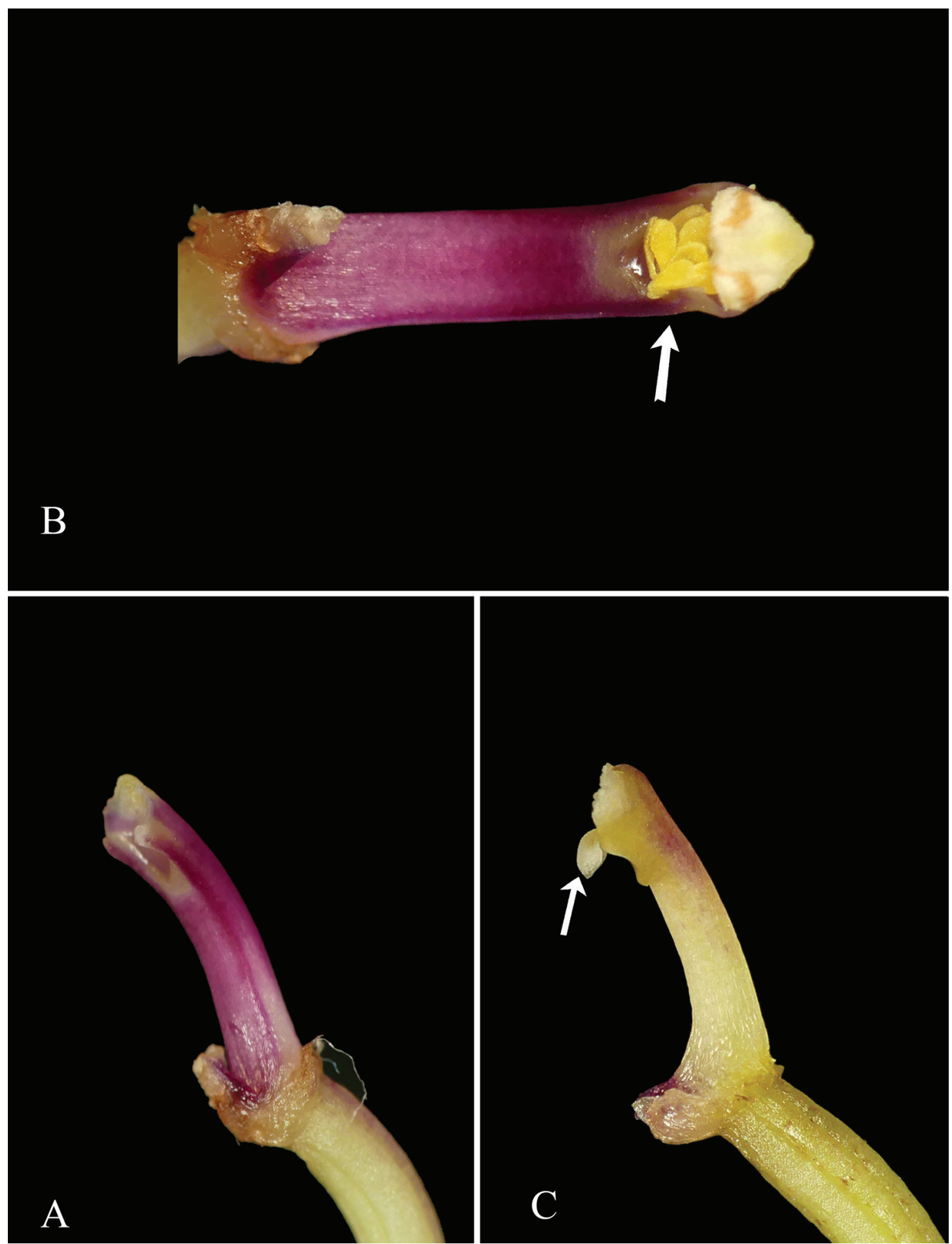

Figure 4. Comparison of the rostellum. A. Column of Octomeria pacii Vélez-Abarca, M.M.Jiménez \& Baquero, with vestigial rostellum. B. The pollinia reaching the stigma in $O$. pacii. C. Column of $O$. deceptrix Luer with pronounced rostellum indicated by an arrow. Photos by Marco M. Jiménez. 
Column red-purple, semiterete, ribbed longitudinally at each side, 3.0-3.5 mm long; the anther subapical and a ventral stigma, clinandrium slightly irregular, rostellum vestigial, foot $0.2-0.3 \mathrm{~mm}$ long. Anther cap white. Pollinia yellow, 8, in 2 sets of 4 .

PARATYPe: Ecuador. Zamora-Chinchipe: near Zamora, 1278 m, 13 December 2019, M. Jiménez 843 (HUTPL!).

Eponymy: Named after Patrick Paci, passionate lover of the forests and slipper orchids of Ecuador and generous donor and supporter of this research.

Distribution and habitat: Octomeria pacii grows as an epiphyte under the shade of small trees covered by mosses and lichens in premontane and lower montane forests over a sandstone plateau of the Cordillera del Cóndor. Plants generally grow in windy areas at elevations of $1000 \mathrm{~m}$. This species has also been found growing in steep slopes of the eastern Andes of Ecuador, near Zamora, at an elevation of $1300 \mathrm{~m}$.

Octomeria pacii is very similar to $O$. deceptrix (Fig. 2B, 3B, 4C), but it differs in the caespitose habit with an inconspicuous rhizome (vs. shortly repent rhizome), the compressed ramicauls ( $v s$. ramicauls terete below, slightly compressed above), leaf narrowly elliptical, $8-15 \times 1.5-2.5 \mathrm{~cm}$ (vs. elliptical-ovate, 5-7 $\times 1.5-3.0 \mathrm{~cm}$ ), the longer ovary, 3.5-4.0 $\mathrm{mm}$ long (vs. 2.5-3.0 mm long). The flowers have translucent white sepals suffused with magenta (vs. white to yellow, often suffused with rose), the dorsal sepal is ovate and wider, $0.9-1.1 \times 0.5-0.6 \mathrm{~cm}, 5$-veined (vs. the elliptical-obovate dorsal sepal, $0.6-0.9 \times 0.2-0.3 \mathrm{~cm}$, 3-veined) and the petals are wider, 3-4 mm wide ( $v s$. 2-2.5 mm wide). The lip is white, marked with magenta, glabrous, obovate, $3.5-4.0 \times 6.0-6.5 \mathrm{~mm}$ ( vs. the lip yellow, suffused with red-purple, oblong, 4.7-5.0 $\times$ $2.0 \mathrm{~mm}$ ), the midlobe suborbicular with a slightly cuspidate apex, ( $v s$. subpentagonal with the apex subtruncate or obtuse,) and the disc with prominent calli (vs. low). It is also distinguished by the laterally ribbed column (vs. smooth) and the autogamous flowers (vs. allogamous). Octomeria pacii shows a unique floral feature: the presence of two longitudinal ribs, one at each side of the column compared to the smooth and terete column of the rest of the species in the genus.

About one year ago, we tracked the species, and we observed capsule production in all flowers that caught our attention. Therefore, four specimens were cultivated for eight months, and the same seed pod production was observed without withering of any flower. While dissecting the flower of the species for the line drawing, it was noted repeatedly that the pollinia easily entered the stigma (Fig. 4B). This because flowers lack a prominent rostellum that prevents selfpollination (Catling 1991) as in other Octomeria species (Fig. 4). Octomeria pacii has a vestigial rostellum (Fig. 4A) and we assume that it could influence the successful production of capsules in each flower. In the future, it should be demonstrated if the species is selfpollinated and if the seed are viable.

Conservation status: This species has been only recorded in the province of Zamora Chinchipe. Populations of this species grow in poorly managed and disturbed forests, where mining is practiced. Although numerous individuals have been found, the species is at risk due to its occurrence outside protected areas where habitat destruction is rampant.

Octomeria panguiensis Vélez-Abarca, M.M.Jiménez \& Baquero, sp. nov. (Fig. 5-7A).

TYPE: Ecuador. Zamora: Chinchipe, Cordillera del Cóndor flank, 890 m, 17 Aug. 2020, L. Vélez, LV 0012 (holotype: ECUAMZ!).

Diagnosis: Similar to Octomeria werneri Luer \& Thoerle in the cleistogamous flowers, but differs by the larger plants (up to $33.0 \mathrm{~cm}$ tall $v s .10 .5 \mathrm{~cm}$ ), shortly repent ( $v s$. caespitose) with lanceolate leaves (vs. narrowly elliptical), the translucent white-colored sepals (vs. light rose-colored), the 5-veined lateral sepals ( $v s$. 4-veined), and the oblong-trilobed lip with the apical lobe tridentate ( $v s$. panduriform with subretuse apical lobe).

Plant large, up to $33 \mathrm{~cm}$ tall, epiphytic, shortly repent. Rhizome stout, 6-8 $\mathrm{mm}$ thick, 6-12 $\mathrm{mm}$ long between ramicauls. Roots slender, flexuous, $1 \mathrm{~mm}$ in diameter. Ramicauls stout, suffused with purple, erect, 12-20 cm long, compressed, ancipitous below, with 4-5 internodes enclosed by imbricating, tubular sheaths, the lower one shorter than the others, which tear with age. Leaf erect, coriaceous, narrowly elliptical to lanceolate, $15-22 \times 2.5-3.5 \mathrm{~cm}$, 


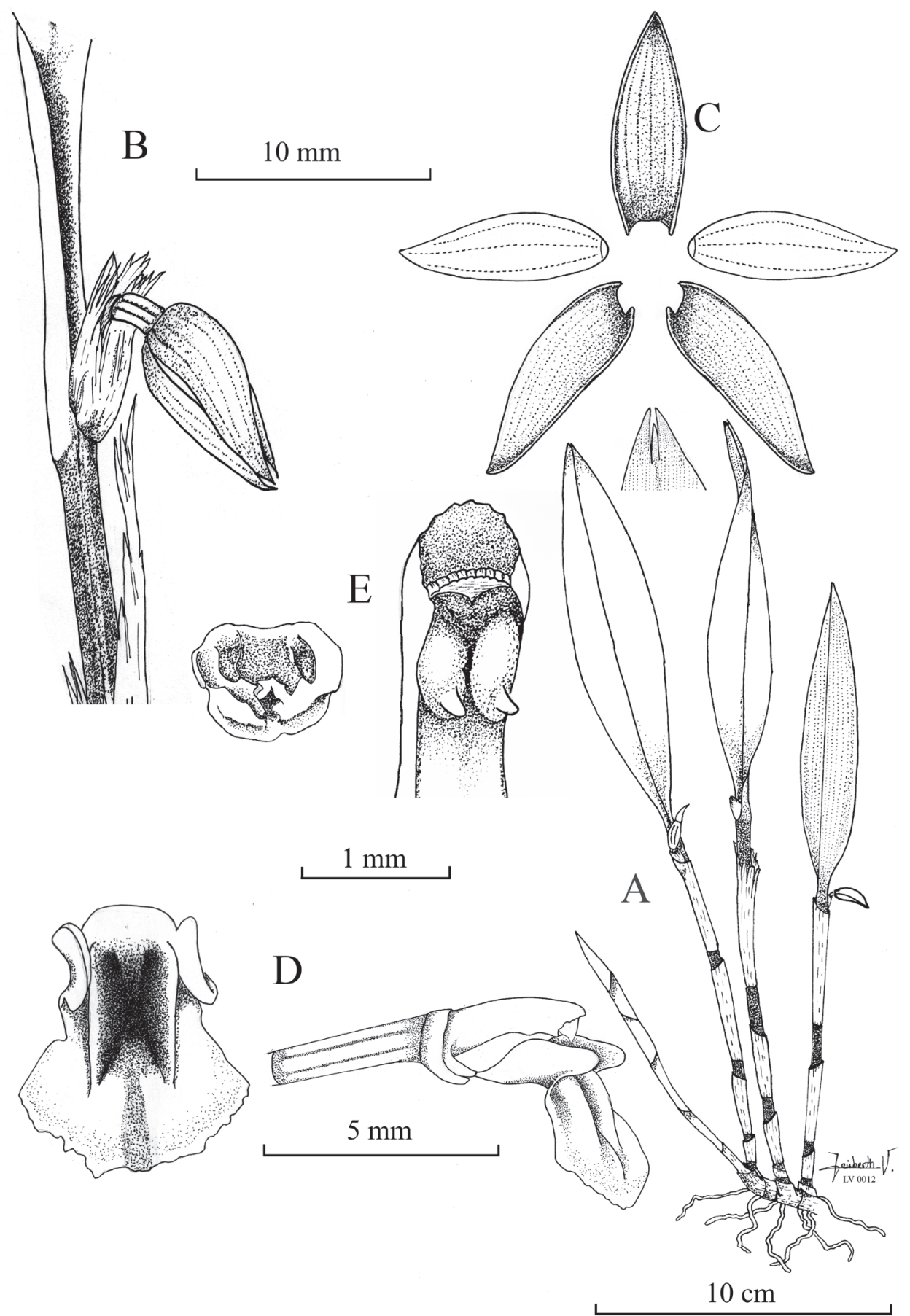

Figure 5. Octomeria panguiensis Vélez-Abarca, M.M.Jiménez \& Baquero. A. Habit. B. Autogamous flower in 3/4 view. C. Dissected perianth. D. Lip in adaxial view and part of the pedicel, ovary, column and lip in lateral view. E. Anther cap in abaxial view and column in abaxial view and apex of the column in ventral view. Illustration by Leisberth Vélez, based on the holotype, Vélez-Abarca LV-0012 (ECUAMZ). 


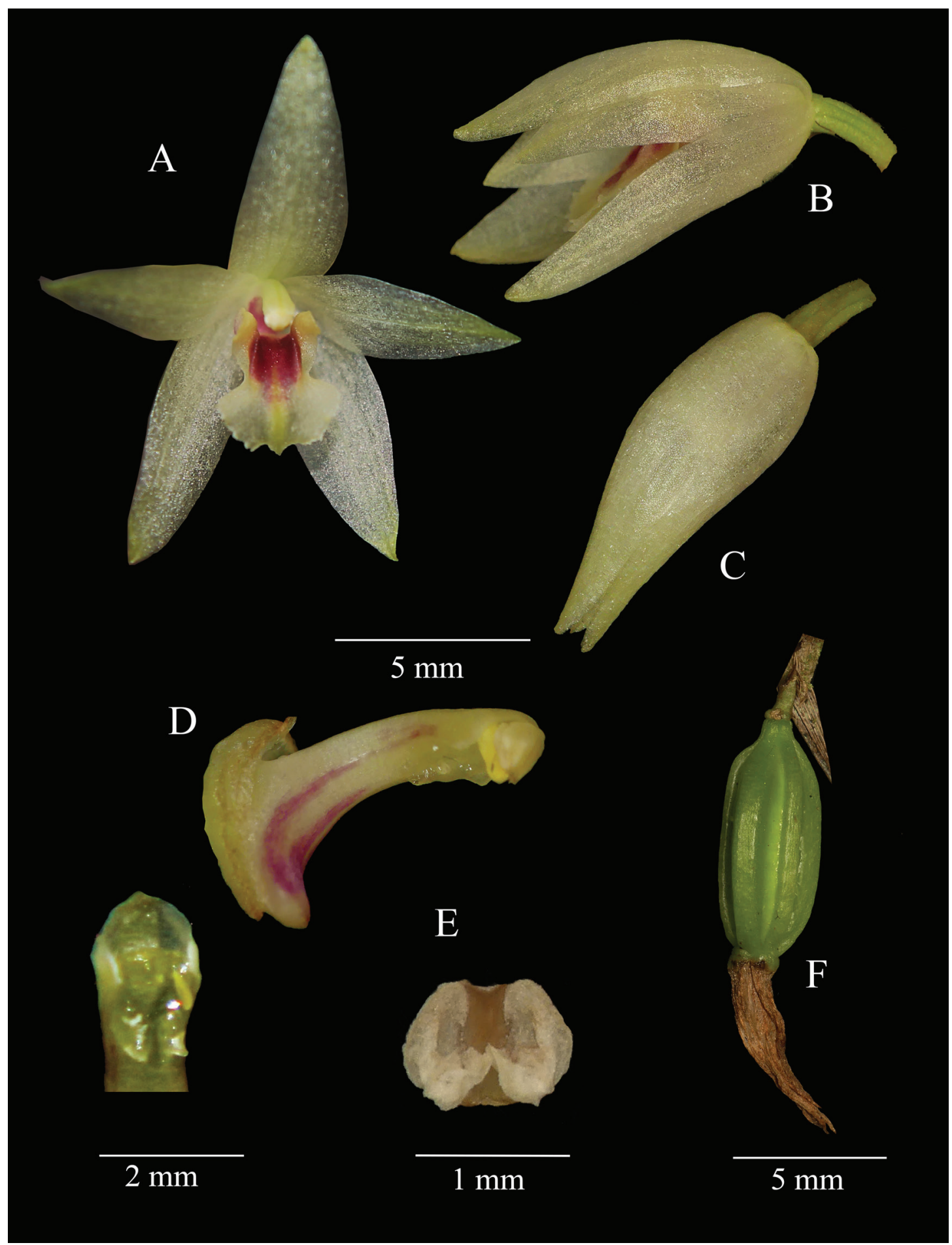

Figure 6. Flower parts and fruit of Octomeria panguiensis Vélez-Abarca, M.M.Jiménez \& Baquero. A. Flower fully open. B. Flower in partially open state. C. Flower fully closed. D. Column viewed laterally. E. Anther cap seen abaxially. F. Capsule. Figure by Leisberth Vélez from photos by Lesiberth Vélez and Marco M. Jiménez. 

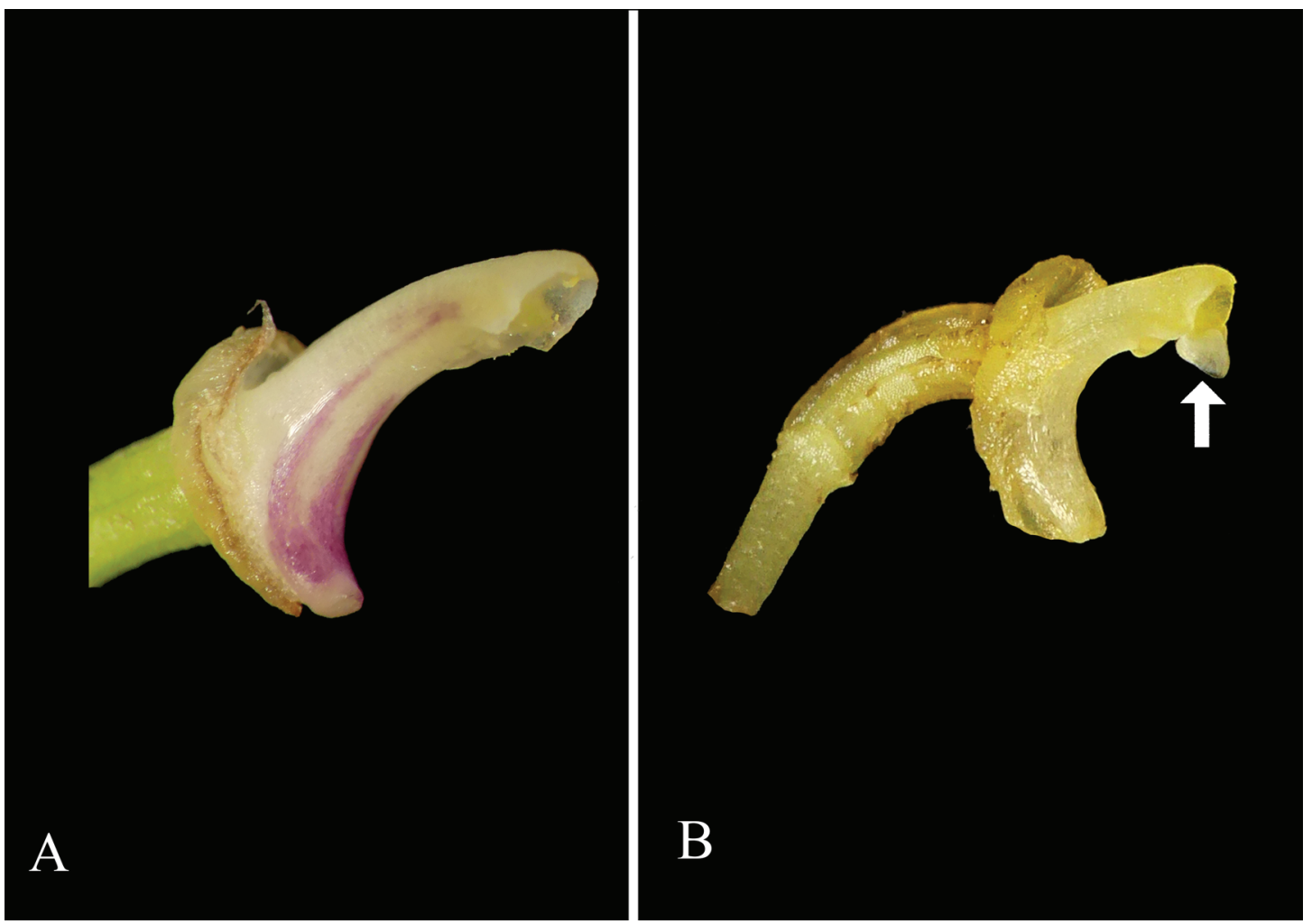

Figure 7. Comparison of the rostellum. A. Octomeria panguiensis Vélez-Abarca, M.M.Jiménez \& Baquero, with vestigial rostellum. B. Octomeria doucetteana Doucette ex L.E.Matthews, with pronounced well-developed rostellum. Photos by Marco M. Jiménez.

cuneate below into a $1.0-1.5 \mathrm{~cm}$ long petiole, the mid-vein sulcate adaxially and slightly carinate abaxially, margin entire, involute, apex tridentate, and slightly acuminate. Inflorescence 1-3 single simultaneous flowers in a fascicle from the apex of the ramicaul, cleistogamous, rarely partially opened, peduncle cylindrical, 1.0-1.5 mm long; floral bract tubular, $3 \mathrm{~mm}$ long; pedicel cylindrical, $4 \mathrm{~mm}$ long; ovary 5-6 mm long, terete, longitudinally sulcate. Sepals translucent white-colored, with yellowishgreen apex, free, glabrous, slightly concave. Dorsal sepal elliptical, acute $1.0-1.2 \times 0.3-0.4 \mathrm{~cm}$, 5 -veined. Laterals sepals, elliptical, acute, slightly oblique, $1.0-1.2 \times 0.3-0.4 \mathrm{~cm}, 5$-veined. Petals translucent white, elliptic to ovate, apex yellowish green, acute, $0.8-0.9 \times 0.3-0.4 \mathrm{~cm}, 3$-veined. Lip whitish yellow, the disc marked with red-purple, glabrous, oblong-trilobed, erose margins towards the apex, 5-6 × 3-4 mm, the lateral lobes erect, oblique, rounded at the tip, antrorse; the middle lobe, broadly spatulate, broadly tridentate at the apex, the margins minutely erose, the disc with a pair of longitudinal calli born close to the base which extend up to the second third of the lip; the base broadly truncate, hinged to the tip of the column foot. Column white semiterete, 3.5-4.0 mm long, stigma ventral, with two short, fang-like structures at the lower side of the stigma, clinandrium slightly irregular, rostellum vestigial. Anther cap subapical $1.0 \times 0.8 \mathrm{~mm}$, white. Pollinia 8 , in 2 sets of 4 , yellow. Fruit cylindrical to fusiform with three longitudinal keels, $6 \times 3 \mathrm{~mm}$.

Eponymy: Named after El Pangui canton, in southeast Ecuador, where the species was discovered.

DistRIBUTION AND HABITAT: Octomeria panguiensis is known only from the Shagmi mountain range in the Cordillera del Cóndor region, Zamora Chinchipe province, southern Ecuador. It grows as an epiphyte, forming dense populations at the bases of trees on the slopes of a sandstone plateau. The elevation range of 


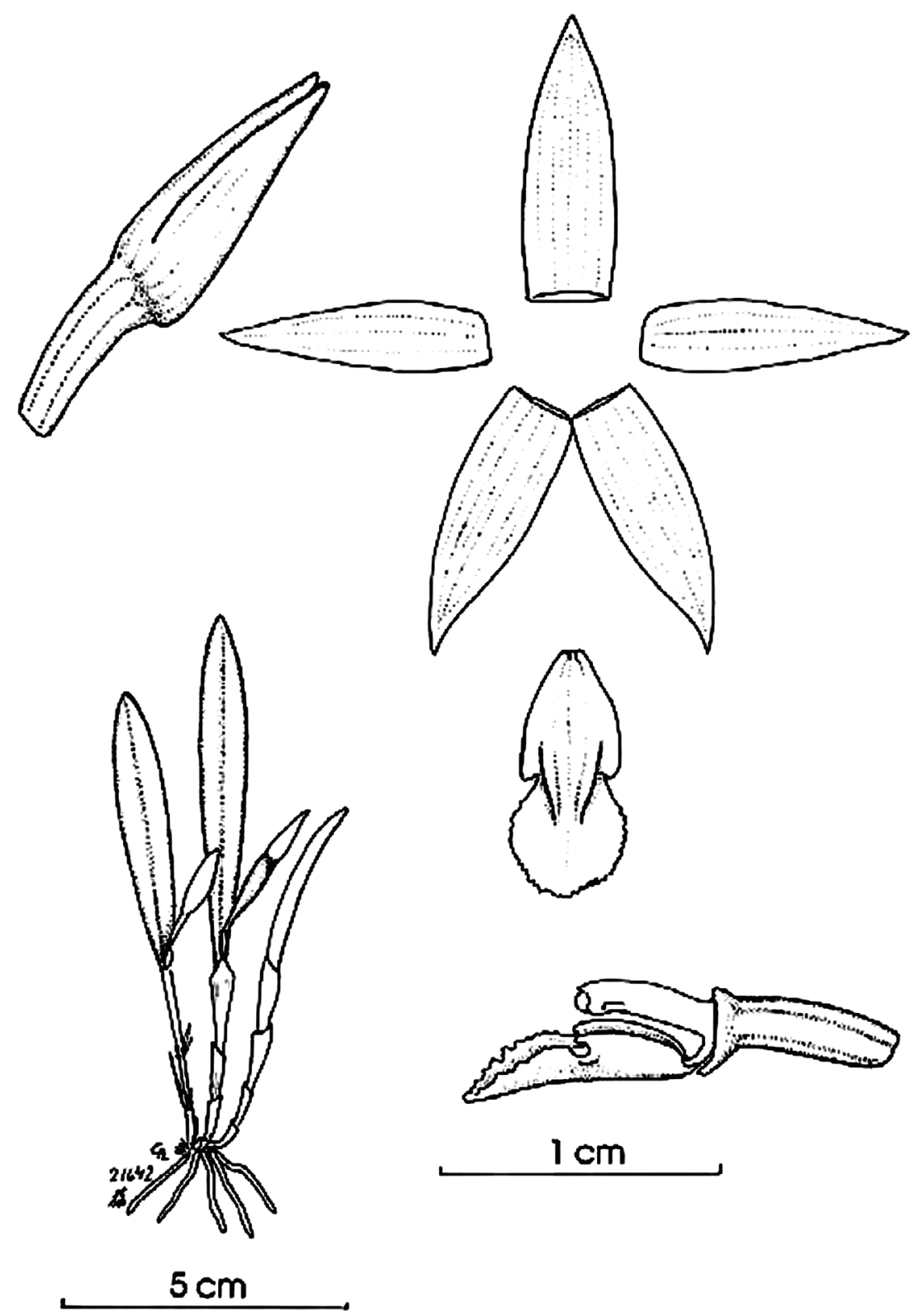

FIgure 8. Drawing of Octomeria werneri Luer \& Thoerle. Original drawings by Carlyle Luer, Courtesy of the Harvard University Herbaria. 
this species goes from 890 to $1000 \mathrm{~m}$ of elevation. It is not selective in its host.

The most similar species to Octomeria panguiensis is $O$. werneri (Fig. 8); both species are found in southeastern Ecuador and are cleistogamous. The main feature that distinguishes them is the size of the plants and flowers, $O$. panguiensis triples in size to $O$. werneri. Also, the leaf-ramicaul ratio is different, $O$. panguiensis has shorter leaves than the ramicauls; in contrast, $O$. werneri has longer leaves than the ramicauls.

Octomeria is mainly characterized by being selfincompatible (dos Santos et al. 2020). Luer (2011) published the first cleistogamous species of the genus from Ecuador, naming it O. werneri. Octomeria panguiensis is the second Ecuadorian species that bears cleistogamous flowers (Fig. 6C) and is self-pollinated. Ordinarily, the rostellum acts as a mechanical barrier that prevents contact between the pollinarium and the stigmatic cavity of the flower, avoiding self-pollination (Catling 1991, Arditti 1992), for example, Octomeria doucetteana Doucette ex L.E.Matthews, has a fairly developed rostellum (Fig. 7B). In O.panguiensis, cleistogamy happens because most of the flowers never open (except for two observed flowers since it was discovered) and due to the presence of a vestigial rostellum (Fig. 6D, 7A) that would malfunction as a mechanical barrier between the pollinarium and the stigma, thus allowing autogamy. It has been possible to observe the flowers of $O$.panguiensis in three states: from about 100 observed flowers in situ belonging to 40 specimens, the most common state was with completely closed flowers. In contrast, partially open and completely open has been observed only once for each case (Figs. 6A-B). No partially open to open flowers have been observed in situ.

Conservation status: The primary forests of the El Pangui canton are characterized by severe human im- pact due to timber and mineral extraction, which leads to the modification and loss of the native vegetation. Octomeria panguiensis is known from a single population in the Cordillera del Cóndor. Considering the high endemism of several taxa in the Pleurothallidinae (for example Octomeria condorensis Luer \& Hirtz, Masdevallia condorensis Luer \& Hirtz, Porroglossum dactylum Luer, Pleurothallis paquishae to) at the Cordillera del Cóndor and one year long in situ research, $O$. panguiensis is not expected to grow elsewhere. Adding that the site where $O$. panguiensis is known from and other potential areas are under mining activities (both legal concessions by the Ecuadorian government and illegal mining), the species described here is considered under threat. Based in the IUCN categorization by applying the B1 criteria (extent of occurrence) and the conditions bi, ii, and iii (continuing decline observed, estimated, inferred or projected in any of (i) extent of occurrence; (ii) area of occupancy; (iii) area, extent and/or quality of habitat; (iv) number of locations or subpopulations; (v) number of mature individuals) and ci, ii and iii (extreme fluctuations in any of (i) extent of occurrence; (ii) area of occupancy; (iii) number of locations or subpopulations; (iv) number of mature individuals) $O$. panguiensis is recommended as an endangered species.

AcKNOWLEDGMENTS. We acknowledge Mark Wilson for helping with language corrections and other observations to the manuscript. To the Ministerio del Ambiente (MAE) for granting the Research Permits No. 037-2019-IC-FLOFAU-DPAZCH-UPN-VS/MA and 21-2019-IC-FLO-FAUDPAZCH-UPN-VS/M. We thank the staff of Harvard University Herbaria for letting us use the drawing of the species for comparisons. We thank Universidad Estatal Amazónica (UEA) and Universidad de las Americas (UDLA) for promoting and funding orchid research in Ecuador. We also acknowledge the reviewers of this manuscript for helping with comments and corrections.

\section{LiTERATURE CITED}

Arditti, J. (1992). Fundamentals of Orchid Biology. New York, USA: John Wiley \& Sons.

Barbosa, A. R., de Melo, M. C. \& Borba, E. L. (2009). Self-incompatibility and myophily in Octomeria (Orchidaceae, Pleurothallidinae) species. Plant Systematics and Evolution, 283(1-2), 1.

Borba, E. L., Semir, J., Shepherd, G. J. (2001). Self-incompatibility, inbreeding depression and outcrossing potential in five species of Pleurothallis (Orchidaceae). Annals of Botany, 88, 89-99

Catling, P. M. (1990). Auto-pollination in the Orchidaceae. In J. Arditti (Ed.), Orchid biology: reviews and perspectives. V (pp. 121-158). Portland, OR, USA: Timber Press. 
Catling, P. M. (1991). A synopsis of breeding systems and pollination in North American orchids. Lindleyana, 6, $187-210$. dos Santos, T. F, Amano, E., dos Santos Forstner, A. C., Toscano de Brito, A. L. V. \& Smidt, E. D. C. (2020). Estudios florales en Octomeria R.Br. (Orchidaceae: Pleurothallidinae). Feddes Repertorium, 131(2), 101-110.

Forster, W. (2007). Estudo taxonômico das espécies com folhas planas a conduplicadas do gênero Octomeria R.Br. (Orchidaceae). Ph.D. Thesis, Universidade de São Paulo, São Paulo, 270 pp.

Forster, W., Castro, V. \& de Barros, F. (2012). Three new species of Octomeria (Orchidaceae: Pleurothallidinae) from northern South America. Kew Bulletin, 67, 487-493.

Johnson, S. D. \& Steiner, K. E. (2000). Generalization versus specialization in plant pollination systems. Trends in Ecology and Evolution, 15, 140-143.

Karremans, A. P. (2016). Genera Pleurothallidinarum: an updated phylogenetic overview of Pleurothallidinae. Lankesteriana, 16(2), 219-241.

Karremans, A. P. \& Díaz-Morales, M. (2019). The Pleurothallidinae: Extremely high speciation driven by pollinator adaptation. In A. M. Pridgeon \& A. R. Arosemena (Eds), Proceedings of the 22nd World Orchid Conference (pp. 363-388). Guayaquil, Ecuador: Asociación Ecuatoriana de Orquideología.

Karremans, A.P., Aguilar-Sandí, D., Artavia-Solís, M., Cedeño-Fonseca, M., Chinchilla, I. F., Gil-Amaya, K., Rojas-Alvarado, G., Solano-Guindon, N. \& Villegas-Murillo, J. (2019). Nomenclatural notes in the Pleurothallidinae (Orchidaceae): miscellaneous. Phytotaxa, 406(5), 259-270.

Luer, C. A. (1998). Icones Pleurothallidinarum XVII. Systematics of Subgen. Pleurothallis Sect. Abortivae Sect. Truncatae Sect. Pleurothallis Subsect. Acroniae Subsect. Pleurothallis Subgen. Dracontia Subgen Unciferia: Addenda to Dracula, Lepanthes, Masdevallia, Porroglossum and Scaphosepalum. Monographs in Systematic Botany of the Missouri Botanical Garden, 72, 1-121.

Luer, C. A. (2001). Icones Pleurothallidinarum XXII. Systematics of Masdevallia. Part Three. Monographs in Systematic Botany from the Missouri Botanical Garden, 86, 510-780.

Luer, C. A. (2006). Icones Pleurothallidinarum XXVIII. Reconsideration of Masdevallia, and the Systematics of Specklinia and vegetatively similar genera (Orchidaceae). Monographs in Systematic Botany from the Missouri Botanical Garden, $105,1-274$.

Luer, C. A. (2010). Icones Pleurothallidinarum XXXI. Lepanthes of Bolivia, Systematics of Octomeria Species North and West of Brazil, Addenda: New Species of Brachionidium, Lepanthes, Masdevallia, Octomeria, Platystele, Pleurothallopsis, and Porroglossum. Corrigenda. Monographs in Systematic Botany from Missouri Botanical Garden, 120, 1-154.

Luer, C. A. (2011). Miscellaneous new species in the Pleurothallidinae (Orchidaceae) excluding species from Brazil. Harvard Papers in Botany, 16(2), 311-360.

Pupulin, F., \& Bogarín, D. (2007). A second species of Restrepiella (Orchidaceae: Pleurothallidinae). Willdenowia, 37(1), 323-329.

Vélez-Abarca, L., Jiménez, M. M., \& Baquero, L. E. (2020). Octomeria candidae (Orchidaceae: Pleurothallidinae), a new species from the Cordillera del Cóndor, Ecuador. Lankesteriana, 20(3), 345-351. 